https://helda.helsinki.fi

\title{
Wars, nation and the welfare state in Finland
}

\section{Kettunen, Pauli Tapio}

Oxford University Press

2018

Kettunen , P T 2018, Wars, nation and the welfare state in Finland . in H Obinger , K Petersen \& P Starke (eds), Warfare and Welfare : Military Conflict and Welfare State

Development in Western Countries . Oxford University Press , Oxford , pp. 260-289 . https://doi.org/10.1093/oso/978

http://hdl.handle.net/10138/313720

https://doi.org/10.1093/oso/9780198779599.003.0010

acceptedVersion

Downloaded from Helda, University of Helsinki institutional repository.

This is an electronic reprint of the original article.

This reprint may differ from the original in pagination and typographic detail.

Please cite the original version. 
Final manuscript of chapter in Herbert Obinger, Klaus Petersen \& Peter Starke (eds.) Warfare and Welfare. Military Conflict and Welfare State Development in Western Countries. Oxford University Press, Oxford 2018, 260-289.

\section{Wars, Nation, and the Welfare State in Finland}

Pauli Kettunen

\section{Abstract and Keywords}

In public constructions of the national past in Finland, two major themes currently predominate: the wars of the twentieth century, including the Civil War of 1918 and the wars against the Soviet Union during World War II, and the making of a Nordic welfare state. The chapter takes the current intertwining of these national narratives as a point of departure for analysing the social policy role of wars in Finland. It examines direct and indirect impacts of experienced or anticipated wars, short-term and long-term social policy measures and outcomes, and institutional continuities and discontinuities. The paper discusses the ways wars have shaped the notion of national agency as a framework of social policies, and identifies multi-layered historical legacies of wars in the making of the welfare state post-World War II. Keywords: war, welfare state, national agency, civil war, social cohesion, rational planning, population policy, Finland, Nordic welfare state

\section{Introduction}

In public constructions of the national past in Finland, two major themes currently predominate: the wars of the twentieth century and the making of a Nordic welfare state. Sometimes they represent rival ideas about the historical core of national agency, but they also intertwine. This paper takes the current intertwining of these national narratives as a point of departure for analysing the social policy role of wars in Finland. From this perspective, the paper also discusses Finland as a specific case within the history of Nordic welfare states.

The dominant public narrative of the making of the Finnish welfare state includes the reconciled confrontation of the Civil War of 1918 
between the socialist Reds and the bourgeois Whites. It also involves images and legacies of national integration during World War II, when Finland was involved in two wars against the Soviet Union: the Winter War of 1939-40 and the Continuation War of 1941-4, as well as the Lapland War of 1944-5 to expel German troops, 'the brothers in arms' of the preceding Continuation War. In political debates, 'the spirit of the Winter War' is often referred to for revitalizing Finnish potential to unite in defence of what are seen as joint national achievements. The welfare state currently appears as such an achievement, and rescuing the welfare state is an argument for a wide range of political objectives, including those of austerity politics.

The rhetoric associating wars with national agency and with the welfare state can refer to real experiences and memories. The casualties of the Civil War of 1918 - including those 12,000 Reds who died in prison camps after the war - amounted to about 38,000 people killed. In World War II, about 700,000 men served as soldiers; of these, 93,000 soldiers and 2,000 civilians died, and about 95,000 soldiers were permanently disabled. The population of the territories ceded to the Soviet Union (more than 400,000 people) was relocated within the rest of Finland. In 1940, the population of Finland was 3.7 million. The political system and the international position of the country were profoundly affected by the experiences and outcomes of wars, which influenced the definition of social problems and solutions, and political battles over the right ways to define and solve social problems.

Wars have influenced social policies by destroying and damaging human life and by changing economic and social conditions, that is, through their direct impact on what can and must be 'constructed' as social problems (cf. Spector and Kitsuse 2011). However, the impacts of wars on social policies have also been mediated through the role they have played in the formation and transformation of the nation state, and national polity and its different actors. Wars have affected the relationship between 'the space of experience' and 'the horizon of expectation' (Koselleck 1979) in national politics and policies. Thus, they have shaped the institutional and ideational frameworks for defining and solving social problems.

The notion of external challenges and an internal national will responding to those challenges is an ingredient of nationalism, especially in small countries. Finland is one of those countries in which the threats, experiences, and outcomes of wars have significantly 
contributed to this mode of thought and action. It reveals itself in the intertwining of the welfare state and wars in current national narratives. These consensual narratives are far from sustainable as historical interpretations, but they reflect an important war-related ideational aspect in the development of Finnish social policies, that is, a concern about the agency of the nation in the world of external challenges and necessities.

This chapter is structured in three parts, corresponding to three periods. Each part takes into account the direct and indirect impacts of experienced or anticipated wars, short-term and long-term policy measures and outcomes, and institutional continuities and discontinuities. The first part encompasses a period of one hundred years from the beginning of nineteenth century until the first years of twentieth century. It includes three wars that played a crucial role in the making of Finland: the Russo-Swedish War of 1808-9, the Crimean War of 1853-6 and the Russo-Japanese War of 1904-5. In the second part, the experiences and outcomes of World War I and the Civil War of 1918 are examined. The third part of the chapter focuses on World War II as a significant phase in the processes combining social policies with concerns about national agency. From this perspective, the role of wartime experiences and the outcomes of the war in post-war social policies are also discussed. The conclusion identifies multi-layered historical legacies of wars in the post-World War II transformations that we, from our modern-day perspective, may call the making of the welfare state, and the focus is, as it is in the chapter in general, on how wars have shaped the notion of national agency as a framework of social policymaking.

\section{Wars in the Making of Finland and its Social Question}

Sweden lost its Eastern provinces in the Russo-Swedish War of 18089, linked with the Napoleonic Wars, and they were reshaped as the Grand Duchy of Finland of the Russian Empire. In the nineteenth century, the Grand Duchy developed into an autonomous nation state. In the borderlands of the Russian Empire, old Swedish legal and religious (Lutheran) institutions and traditions persisted, utilized by, and intertwined with, the new Finnish nationalism that was largely compatible with the Russian imperial interest of promoting the separation of Finland from Sweden. 
The conclusions drawn by the new Emperor Alexander II from the experiences of the Crimean War of 1853-6 launched a period of reforms in the empire. In the loyal Grand Duchy of Finland, the old Swedish Four-Estate (nobility, clergy, burghers, farmers) Diet was reintroduced in 1863 - the year of the Polish uprising against the Russian Empire that led to Poland losing its autonomy. Space for political debate and civic organization opened up in the 1860s. 'The people' emerged in the debates of the political elite as a target for education and 'national awakening' and as the source of political legitimacy. Conflicts tended to be shaped as struggles for the right way and the privilege to speak in the name of 'the people'. This was evident in the controversies between the so-called Fennomans and the so-called Liberals from the 1860s onwards, concerning the role of language, culture, and constitution in the making of the nation, and it was also characteristic of later political conflicts concerning the right ways of defending Finland's autonomy and the handling of social class divisions (Alapuro 1988; Klinge 1993; Pulkkinen 1999).

Economic reforms in the 1860 s and 1870 s removed mercantilist privileges and regulations, and were completed by further reforms that gradually realized the principle of a free labour market. Accordingly, the Bill of Poor Relief was revised in 1879 in accordance with the liberalist work-discipline spirit of the English Poor Law of 1834, imported to Finland via the Swedish Bill of Poor Relief that had been revised a few years earlier. Poor relief and care of the sick were the responsibility of municipalities that were, in 1865, separated from the parishes of the Lutheran Church. At that time, Finland was a poor rural country in which extreme natural conditions imposed major economic constraints. The last nationwide famine, in 1866-8, and the diseases associated with it, killed approximately 150,000 people, about 8 per cent of population (Häkkinen and Forsberg 2015).

In a small country like Finland which, even by Nordic standards, was late to industrialize, international comparisons came to play a prominent role in the definition of social problems and solutions. From the second half of the nineteenth century onwards, such comparisons became integral to the way the educated elite analysed society and defined socio-political tasks. It was a question not only of imitating more developed countries but also of deliberately attempting to anticipate social problems by taking on board experiences from 'more civilized' countries. One may characterize this mode of thought and 
action as the avantgardism of the intellectual elite of a peripheral country. For this pattern of thought, the outside world provided a framework of external preconditions and constraints, hopes and threats, intriguing but also alarming ideas, examples of both model and unpleasant societal arrangements, and opportunities to be grasped as well as necessities to be responded to.

A long period of time often elapsed between the definition of a social problem and its solution, with the help of imported ideas on the one hand and the practical application of these definitions and solutions on the other. However, as early as the 1880s and 1890s, when the far from democratic system of the Estates still operated, and there was no labour movement proper, two acts of principal importance were adopted: the Act on the Protection of Industrial Workers, which established the institution of factory inspection (1889), and the Workers' Compensation Act (1895). Finland was not a laggard when it came to the statutory regulation of industrial work-indeed it was not even a latecomer among the Nordic countries. Thus, for example, the adoption of a special female factory inspectorate was launched in Finland in 1903, ten years earlier than in Sweden (Kettunen 1994, 32-91; Kettunen 2001b, 233).

The state was the central agent in the integration of Finland in expanding industrial capitalism, as it was in other Nordic countries too. Bureaucratic interest in increasing state revenues motivated marketpromoting reforms, and political and economic elites adopted a statecentred image of a national economy that from the 1860s had its own currency, customs, and state railways. The latter provided an important infrastructure for Finnish nation-building, while also strengthening the connection of the Grand Duchy to the capital of the Russian Empire, Sankt Petersburg, and also playing a role in Russian military plans (Polvinen 1962). As a result of the infrastructural role of the state, a considerable part of what can be called the 'aristocracy of labour', for example locomotive drivers, had the formal status of civil servants and corresponding social benefits, including pensions (Kettunen 1976).

Indicative of the autonomous status of the Grand Duchy, a Finnish Army, separate from the Russian Army, was founded in 1878. It was based on general conscription by ballot, with a peacetime strength of 5,600 men. In 1901, the Russian government decided to extend the empire's conscription system to Finland and to dissolve the separate Finnish Army. Because of Finnish resistance, however, the 
introduction of imperial conscription in Finland largely failed. In 1905, the Russian government backed down on this attempt, and instead of imperial conscription, the Grand Duchy was obliged to contribute financially to the costs of the Russian Army (Screen 1996).

Conscription was a major issue in the conflict that emerged between the Finnish polity and the Russian Empire at the turn of the century. It was a collision between the consolidation of Finland as an autonomous political, economic, and cultural unit, and the Russian effort to promote a stronger administrative unity of its empire. However, imperial integration policies temporarily lost much of their force, as the Russian Empire was weakened by its defeats in the Russo-Japanese War of 1904-5. This had longstanding consequences for Finnish polity and society. In connection with revolutionary turmoil in Russia, a breakthrough of mass politics and the labour movement took place in Finland. After the General Strike of 1905, representation through the Estates was suddenly replaced by the most democratic representative system in Europe. Even though restricted by the re-established authority of the emperor, after 1906 Finland had a political system based on a universal franchise that included women (Jussila 1999, 7991).

National integration in terms of increased cultural homogeneity (Alapuro 1988, 92-110) greatly contributed to the development of class conflicts. The nation as 'imagined community' (Anderson 1983) provided socially subordinated groups with criteria for a critique of prevailing circumstances and with a frame of reference within which they could politically interpret and generalize their local experiences of injustice. In one of the most rural countries of Europe, one of the - in relative terms - largest labour movements in the world emerged. The strength of the Finnish labour movement was based on its success in creating an alliance between urban workers and rural landless workers and tenant peasants. Reflecting this background, the Social Democratic Party was considerably larger than the trade unions in quantitative, social, and territorial terms.

The discourse of the 'social question' included several 'questions': a 'labour question', a 'tenant question', and a 'landless population question'. Often the concept of a labour question referred to all urban and rural social problems and divides. Conflicts between the Socialists and the bourgeois parties were evident, yet social policy reforms were, in varying ways and with divergent intentions, included in the 
programmes of all parties. Laws concerning labour protection, regulation of labour relations, and unemployment funds were legislated by parliament (Eduskunta) before World War I. However, only a very few of them were implemented as the legislative power of parliament was restricted by the authority of the Russian Emperor, who frequently refused to confirm an act.

\section{World War I, the Civil War, and Divergent Visions of Social Peace}

\section{World War I in Finland}

Through the connection with Russia, World War I greatly affected Finnish society and economy. The war was experienced as an extended presence of Russian military units; restrictions on civic activities by the imposition of martial law; reorganization of industrial production to serve the needs of Russian warfare; large fortification works and associated labour mobility, and vast unemployment after the end of these works; accelerating inflation; and finally the shortage of food. Particular 'war taxes' were introduced without obtaining parliamentary consent that was normally required for decisions on taxation (Linnakangas 2015).

However, Finland did not directly become a World War I battlefield and the Finns also avoided compulsory service in the Russian Army. There were, however, Finnish officers who had made their careers in Russia, Carl Gustaf Emil Mannerheim being the most famous example. After the beginning of World War I, Finnish volunteers joined both the Russian Army and the German Army: 700 in the former and 2,000 in the latter. The young men joining the German Army were mobilized through a clandestine organization of antiRussian activists. After returning to Finland at the beginning of 1918, these Jägers, who were prepared to battle against the Russians, came to form the core officer group of the White Army in the Civil War-under Commander-inChief Mannerheim, a general in the Russian Army who had returned to Finland after the revolution.

Parliament was not permitted to assemble in the early years of World War I. Parliamentary elections were, however, arranged in 1916, and for the first time the Social Democratic Party gained a majority, winning 103 seats out of a possible 200. Parliament met again after the 
Russian February Revolution in 1917, and a national coalition government of socialists and the bourgeois parties was formed. The head of government came from the Social Democratic Party.

A very rapid mobilization of workers in trade unions took place in the spring of 1917. A traditional key objective of the international labour movement, the eight-hour working day, proved to have particular mobilizing power. Many trade unions had already compelled employers to accept this norm before parliament passed the Act on Eight-Hour Working Day. Some of the social policy edicts that parliament had accepted before World War I were confirmed after the February Revolution: an act extending workers accident insurance and another regulating and supporting voluntary unemployment funds. Soon after the formation of the socialist-led coalition government it became obvious that the economic and social situation was worsening. Less grain could be imported from Russia, leading to a shortage of food; inflation accelerated; and mass unemployment emerged as fortification works ended (Haapala 2014).

Yet, as the Finnish sociologist Risto Alapuro (1988, 150-60) points out, these socio-economic troubles were not uniquely Finnish and cannot explain why a civil war began less than one year after the national cross-class enthusiasm of the spring of 1917. In order to understand this, we must pay attention to two major questions that emerged after the February Revolution. One was the question of what body would assume supreme authority after the emperor ceased to rule, and the other concerned the organization of the coercive power of internal order and security after the replacement of a police force that had been largely 'Russified' in previous years. In the context of World War I, and closely linked with different phases of the Russian Revolution, these two unresolved questions gave impetus to the conflicts that resulted in a confrontation between two armed political forces that emerged in a weakly coordinated fashion on the basis of the earlier established class-based political divide.

\section{The Civil War}

A decisive turn occurred between July and August 1917. The Social Democrats, aiming to extend national autonomy and to raise parliament to a dominant position in the political system, pushed through the so- 
called law on authority. The law left only foreign policy and military affairs in the sphere of authority of the provisional government of Russia and proclaimed the full internal autonomy of Finland. The provisional government was unwilling to concede this and dissolved parliament with support from bourgeois groups. This also meant the end of coalition government. The Social Democrats did not recognize the dissolution of parliament, but nevertheless self-confidently participated in the new election in October 1917, and shockingly lost their majority. While still participating in parliamentary work, the Social Democrats did not fully recognize the legitimacy of the decisions made by the new parliament and the bourgeois government. At the same time, the radicalized mass of workers, in part together with Russian soldiers still remaining in Finland, formed a force to a large extent outside of the Socialist leaders' control (Upton 1980; Siltala 2014).

After the October Revolution, the achievement of full national sovereignty became an urgent issue for all Finnish parties. For the Social Democrats, the decisive factor was that the Bolsheviks, now in power, had been the only party in Russia that had declared willingness to approve Finland's independence, whereas, among the bourgeois groups, the fear of Socialist revolution urged the separation from Russia. In December 1917, Finland was declared independent and the Bolshevik government recognized this independence. This did not, however, prevent the escalation of political confrontation into a fullscale civil war at the end of January 1918, with the left forming a Red government and assuming revolutionary power.

Decision-making in the Social Democratic Party and other workingclass organizations prior to the abortive revolution was confused and fragmented, and there were controversies about the legitimacy of an armed revolution; yet only a few leading Social Democrats eventually declined to participate and no one joined the opposing side. The notion of defending the progressive course of history that had been reversed by the events of July and August 1917 contributed to the legitimacy of the decision. Bolshevist influences and encouragement played a role, but it was only after the total defeat of the revolution that the labour movement was divided into Social Democrats and Communists.

The Red government was formed by leaders of Social Democratic Party and trade unions, and it dominated Southern Finland and the largest cities. The bourgeois government had fled to Ostrobothnia, a 
province of independent farmers with their own particular political and cultural traditions, which became the stronghold of the White Finland mobilization and, later, of the White legacy of the Civil War. The strength of both sides, the Red Guards and the White Guards, was about 80,000 troops. The Red Guards, a poorly trained army with hardly any military expertise, received arms from Russia and were assisted by Russian soldiers; however, the withdrawal of Russian troops from Finland was continuing and the peace treaty between Soviet Russia and Germany in March 1918 further diminished this source of support. The White government, in turn, received support from Germany, which not only trained the Finnish Jägers but also sent to Finland a first-rate military unit, the Baltic Division, which played a significant role in the last phase of the war. The German troops conquered Helsinki in April, and on 16 May 1918 a victory parade of the White Army, led by General Mannerheim, marched through the city.

Among the 38,000 casualties of the Civil War, about 10,000 died in battle; the rest were killed in executions outside of military engagement and in prison camps after the war. Seventy-five per cent of casualties were on the Red side. Social policies concerning invalids, widows, and orphans were spoils of the victors. Soon after the Civil War, a law on pensions was passed for those wounded or those having lost a provider on the White side. Until World War II, war invalids on the Red side were only eligible for support through poor relief, and one of the ways of assisting Red orphans was to send them to be re-educated in Ostrobothnian White farmer families (Kaarninen 2008). However, assistance for Red widows and orphans was a focus of labour movement activities after the Civil War (Saarela 2014).

\section{Strategies of Social Peace}

Despite the counter-revolutionary outcome of the Civil War, Finland was, by the constitution of 1919, established as a parliamentary republic. Again, this solution had its antecedents in international transformations. The alliance of the White winners with the German Empire lost its basis when Germany not only lost World War I but when the empire itself was also dissolved through revolution. In Finland, the parliamentary form of democracy persisted throughout the 1920s and 1930s, even though it was threatened and limited by right- 
wing pressure, especially in the early 1930s. The persistence of democratic forms made Finland exceptional among the new nation states created through the collapse of multi-ethnic empires at the end of World War I. Any explanation of this exceptionality must recognize that Nordic political traditions had played a crucial role in Finnish nation building.

However, the outcomes and memories of the Civil War became an integral part of social, political, and cultural structures. Thus, the Whites controlled military power in the army and in the vast, semiofficial paramilitary Civil Guards organization. The White legacy of the Civil War, including a view of Russia and the Soviet Union as the enemy to be sooner or later confronted in a war, was mediated through military education in an army that was based on general conscription. Through conscription, this legacy also became an ingredient of the ideal of masculine citizenship. At the same time, general conscription implied the need for strategies for national integration and popular legitimation of the regime, as a great many of the conscripts came from families with Red-side experiences and memories (Ahlbäck 2014).

To the White winners of the Civil War, the free landowning peasant became the symbol of the White Army as the antithesis of the harmful Red alliance between urban workers and the rural, landless population. A free independent peasantry also constituted the ideological centre around which 'social peace' had to be 'rebuilt' and defended against the threats associated with the collectivism of wage earners (Kettunen 1997, 103-24). On the basis of previous plans, land reforms were carried out rapidly after the Civil War. These reforms 'liberated' tenants, transforming them into landowning small-scale farmers, and facilitated the colonization of the landless, rural proletariat. The mode of thought and action according to which social peace should be based on political democracy and an independent freeholder peasantry as the core of the nation, was especially characteristic of the Agrarian Party, which gained a powerful position in the political system in the 1920s.

However, efforts to foster national reconciliation after the Civil War also included legislative reforms concerning industrial working life. Politicians and civil servants representing social liberal traditions took up earlier plans of regulating individual employment contracts and collective interest conflicts. Inspiration was taken from a new international organization that was designed to combine the objectives of international peace and social peace, the International Labour 
Organization (ILO), founded in 1919 as an autonomous part of the League of Nations and as Versailles' answer to Bolshevism. This labour peace orientation was also inspired by Nordic cooperation, not least in the wider context of ILO activities (Petersen 2006; Kettunen 2013).

In the early 1920s, parliament passed acts on employment contracts (1922), collective agreements (1924), and the mediation and arbitration of industrial conflicts (1925). These reforms were designed to facilitate a shift towards a comprehensive regulation of labour relations by collective agreements between trade unions and employers. However, this vision was not realized prior to World War II, as employers, especially those in the wood processing, textile, and other manufacturing industries, successfully adhered to a policy rejecting collective agreement whilst utilizing repressive, ideological, and paternalist company welfare means against trade union influence. The ideology that made 'the will to work' of the independent farmer the core of social peace provided ideological legitimization for the policy of industrial employers.

Labour law reforms were not costly. A far more expensive social reform, also motivated by the integrative conclusions drawn from the Civil War, was that of compulsory education. The act was passed in 1922, and it increased the responsibilities of municipalities in which decision-making had been democratized by the legislative reform in 1917. The new Bill for Poor Relief of 1922 included more modest changes in current municipal practices. Taxation was reformed in the early 1920 s at state and municipality levels, and the principle of progressivity was implemented by a law of 1920 in the state-level taxation of income (Lindberg 1934; Linnakangas 2015).

Discussion and planning for social insurance had begun in the 1880s, but before the 1920s only workers' accident insurance had been introduced (1895) and then extended (1917). The first act regulating and facilitating voluntary funds was passed in 1897, with a focus on sickness provision. In 1917, an act permitting voluntary unemployment funds established by trade unions was passed, an embryo of the socalled Ghent System in Finland. In post-Civil War debates on options to extend social insurance, the relative priority of sickness insurance and old-age insurance became an issue of dispute. While the sickness insurance of wage earners was the first priority of the Social Democrats, the Agrarian Party disliked social benefits that were 
targeted only at wage earners, and it put old-age and disability insurance before sickness insurance. After much debate, the Old-Age and Disability Insurance Scheme was legislated in 1937, after compromises between the coalition partners of the new government, the Social Democrats and the Agrarian Party. An act on sickness insurance did not become law until 1963 (Kettunen 2001b).

Labour Movement in a Post-Civil War Nordic Country After the abortive revolution, the Finnish labour movement was divided between Social Democrats and Communists. The Communist Party of Finland was illegal until 1944, and its leaders, the former heads of the Red government of 1918, lived in exile in the Soviet Union. Most were killed in Stalin's purges in the late 1930s. In the 1920s, the Communists and their sympathizers nevertheless had opportunities to act in public labour organizations, most notably in the trade union movement (in which they held leading positions in the 1920s) and even in parliament. In 1930, those categorized as Communists were excluded from public political arenas. In terms of electoral support, the Social Democratic Party was still the largest political party in Finland in the 1920s and 1930s. However, in different ways, both major wings of the labour movement were preconditioned by the post-Civil War regime, which did not provide a favourable context for comprehensive political projects that would include less than the goal of a socialist society but more than particular piecemeal social policy reforms.

Support for the labour movement in Finnish parliamentary elections in the 1920s and the late 1930s was at the 'Nordic' level, close to 40 per cent, but it was unthinkable that the Social Democrats could have achieved a leading position in defining the political agenda in the same manner as in other Nordic countries in the 1930s. This remained true after World War II. The Social Democrats faced the Communists as their fierce rivals in the labour movement after the Civil War and more so after the Continuation War when the Communist Party gained a legal status. The Agrarian Party (from 1965, the Centre Party) played a central role in the political system and in social policies after World War II, both as an opponent and as a coalition partner of working-class parties. Agricultural policies were closely connected with social policies; these were two policy sectors that partly represented competing views on the problems of social order. And until the 1960s, the power of cultural conservatism still reflected the heritage of the 
counter-revolutionary White victory in 1918 , a continuity that was far from totally broken by the post-World War II political changes.

'Nordic' was an attribute of Finnish society, but its meaning was a matter of political contestation, partly as a result of conflicts concerning the position of the Swedish language in Finland, but also because of a charge following the confrontation of the Civil War. In the White heritage of the Civil War, 'Nordic' was associated with the idealized tradition of the free Nordic peasant and local community, whereas for the Social Democrats 'Nordic' in the 1930s began to represent democracy, in contrast to authoritarian regimes and the prevailing state of industrial relations in Finland. The concept of Nordic democracy, as it was defined in the cooperative undertakings of Nordic Social Democrats in the 1930s (Kurunmäki 2011), included a combination of parliamentary political democracy and institutions of collective negotiation and agreement in labour markets. The argument of the Social Democratic trade union leaders in the 1930s was that, while Finland was a Nordic society, it did not fulfil the criteria of the Nordic democracy (Kettunen 2006, 56-9).

In any case, for the development of the notion of Finland as a Nordic democracy, the coalition of the Social Democratic Party and the Agrarian Party in the late 1930s was important. This Scandinavian-type coalition of 'the worker and the farmer' crossed the boundaries of the $1918 \mathrm{Red} /$ White conflict and contributed to national integration and the stabilization of parliamentary democracy_although the limits of democracy were marked by the illegality of the Communist Party until 1944. The so-called Nordic orientation of the Finnish foreign policy in the late 1930s became associated with 'Nordic democracy', a way of defining Finland's position in a world of threatened democracy and the increasing danger of war.

\section{World War II: National Agency and Wartime Questions}

\section{Finland in World War II}

In October 1939, after preceding diplomatic messages to Finland in 1938/9, the Molotov-Ribbentrop Pact in August 1939, and the British and French declarations of war on Germany after its invasion of Poland, the Soviet Union invited representatives of Finland to negotiate 
in Moscow. The Soviet leaders demanded a territory exchange that would push the Finnish-Soviet border farther from Leningrad. They also wanted to obtain a military base on the northern coast of the Gulf of Finland. The Finnish response did not meet Soviet demands, and the Soviet military offensive started on 30 November 1939.

The Finnish resistance proved stronger than Stalin had expected, both militarily and in terms of national unity. The Winter War was an event of great international interest during the otherwise relatively undramatic first winter of World War II. The war ended in March 1940. About 27,000 Finns were killed; the number of Soviet casualties was much higher. Finland ceded one fifth of its territory to the Soviet Union as well as a naval base on the Gulf of Finland. The treaty did not require the Finnish population to leave the ceded territory, but practically the entire population chose to relocate. About 410,000 Finnish Karelians, or 12 per cent of Finland's population, were relocated to other areas of Finland. During the Continuation War of 1941-4 most of the displaced population returned to Karelia, but in summer 1944 they were evacuated again.

After the Winter War, Finnish political decision-making was influenced by further Soviet pressures, fears caused by the Soviet annexation of the Baltic countries, and the desire to reclaim what had been lost in the Winter War, partly inspired by right-wing nationalist visions of a Great Finland that would extend to Eastern Karelia (which had never before belonged to Finland). After the summer 1940, Finland gradually aligned more closely with Germany, and in the spring of 1941, the Finnish military joined the German military in planning for the invasion of the Soviet Union. In late June 1941, Finland was once again at war with the Soviet Union.

The war was described as the Continuation War, implying that it was a defensive continuation of the Winter War with a distinctly FinnishSoviet rationale; yet Finland was now in fact in alliance with Nazi Germany and contributing to Hitler's Operation Barbarossa. In the offensive phase, Finnish troops proceeded to the East, far beyond the country's old border, and occupied Eastern Karelia. After the German defeat at Stalingrad, Finnish political and military leaders began to seek a way out of the war. The powerful Soviet offensive in June 1944 urged a solution. In September, an armistice treaty was signed between Finland, the Soviet Union, and the United Kingdom, which in 1941 had also declared war on Finland, although without subsequent military 
action. A most urgent feature of the treaty was a focus on expelling German forces from Finland: there were 213,000 troops in Northern Finland at that time. The so-called Lapland War began in September 1944 and ended in April 1945, when all German troops had withdrawn. The control commission of the Allies, dominated by the Soviet Union, controlled the implementation of the armistice treaty until its conditions were confirmed by the final Peace Treaty of Paris 1947. However, Finland was one of the few countries participating in World War II to have never been occupied.

The number of Finns killed in the Continuation War exceeded 65,000; in the Lapland War the number was less than 1,000. Territorial losses included those ceded to the Soviet Union after the Winter War and the area through which Finland had access to the Arctic Ocean, and a naval base close to Helsinki was hired by the Soviet Union (although they withdrew from it during the so-called 'first détente' in 1955). Finland had to pay large war reparations; it also had to put wartime leaders on trial. Prison sentences were handed down to eight political leaders, including President Risto Ryti and the leading Social Democrat Väinö Tanner, but not Marshall Mannerheim, who was Commander-in-Chief of the White Army in 1918 and the Finnish Army in the wars of 193945, and president of the Republic in 1944-6. Mannerheim had gained status as the most respected national figure, and Stalin obviously took this into consideration.

The armistice treaty of 1944 opened the way for political changes. The Communist Party ceased to be illegal and became a major political force, and organizations categorized as fascist or anti-Soviet were banned instead. They included the vast paramilitary Civil Guard organization that had been built on the basis of the White guards in 1918 and its sister association, Lotta Svärd, a very important organization mobilizing women in the war effort. The Finnish League of Companions in Arms was also proscribed. This had been founded in 1940 after the Winter War to provide social support and assistance to soldiers and their families, war invalids, widows and orphans, and to control political opinion and broader popular views, especially among workers. Several young Social Democrats were active in this organization, and after the war many of them became leading figures in the Social Democratic Party and in the struggle against Communists in the labour movement. 
Controversial Legacies: Wartime National Unity or the Post-War Political Turn

Significant continuities appeared through wartime and postwar political changes and associated social policy orientations. Controversial post-war accounts of what had been the most important and permanent changes reflected those continuities. The accounts were politically influential in post-war Finland, and pointed either to the overcoming of Civil War cleavages in the national unity of the wartime experience, especially during the Winter War, or to the extension of democracy by the political turn after the end of the Continuation War.

The self-definition of the academic discipline 'social policy' was shaped by persons active in various wartime social policy initiatives. They influentially interpreted wartime problems and solutions as the decisive reinforcement of social solidarity and social policy thinking.

In the view of leading post-war social politicians such as Heikki Waris, the first Professor of Social Policy at the University of Helsinki from the late 1940s, the so-called January Engagement during the Winter War in 1940 was the 'historically most important' social policy achievement of the wartime period (Waris 1973, 24-5). The January Engagement was a considerably short joint declaration, in which the national central organizations of trade unions and industrial employers promised to negotiate on common issues in the future. Employers were now ready to soften their views on trade unions, as it was important to convince Nordic and Western opinion that Finland, a democratic Nordic country, was the target of Soviet aggression. The practice of mutual negotiations was institutionalized by corporatist representation in wartime economic regulations. After the Continuation War, at a time of rapidly increasing trade union power, this practice was modified into the system of collective labour market agreements, decades later than in Denmark, Sweden, and Norway.

Law-based social solidarity was extended through the provision of benefits to disabled soldiers and the families of fallen soldiers in the form of pensions and support for employment and education. The crucial role assigned to voluntary organizations could be seen as evidence of reinforced national unity. Close links were established between voluntary organizations and governmental authorities at central, provincial, and local levels in managing wartime production, 
distributing and allocating scarce labour resources, and arranging social support. In new national umbrella organizations, working-class and bourgeois associations cooperated across political borders (Waris 1973, 24-6; Urponen 1994, 213-16).

The wartime legacy of national integration included these home front experiences and what was called 'the spirit of companions in arms'. It has been popular to explain later compromises in social and labour market policies, for example the pension reform of 1961 and the beginning of the so-called incomes policy in 1968, through the shared battle experiences and companions-in-arms spirit of the men who now met each other as trade union leaders and employers. In terms of empirical evidence, this explanation proves to be questionable as it bypasses interest-based calculations (Julkunen and Vauhkonen 2006, 289-319). It is true, nevertheless, that in the municipal policies of many cities, in particular, the so-called 'companions-in-arms axis' between Social Democrats and Conservatives was effective during post-war decades.

In post-war national historical narratives (Kinnunen and Kivimäki 2012), an unbroken theme has emphasized that wartime efforts and sacrifices had preserved the country as unoccupied, independent, democratic, Nordic, Western, and neutral, although within the limits of a special relationship with the neighbouring Soviet Union. According to this account, the armistice treaty heralded a period of injustice and danger, but Finland survived the threat of Communism.

In 1945, the Communists, the Social Democrats, and the Agrarian Party formed a coalition government, but this collaboration, and the Communist participation in government, only lasted until 1948. Within the trade union movement, the Social Democrats were dominant from the late 1940s. Nevertheless, with a solid electoral base of around 20 per cent of the electorate until the 1970s, as well as with their strong positions in many trade unions and real and assumed support from the Soviet Union, the Communists could be identified as having presented a major challenge to national integration (Rainio-Niemi 2008). After the 1966 elections in Finland, resulting in a socialist majority in parliament, a so-called popular front government was formed, consisting of Social Democrats, Communists, and the Centre Party (the former Agrarian Party). The Communists became involved in reformist politics through coalition governments with the Social Democrats and the Centre Party, as well as through cooperation with the Social 
Democratic majority in the trade union movement. The process resulted in political integration but also in an actual, although not formal, split within the Communist Party, between the reformist majority and the minority intent on preserving its strong loyalty to the Soviet Union and proletarian internationalism.

However, instead of celebrating and defending wartime national solidarity, many critics at the time, as well as later commentators, identified the end of the Continuation War in 1944 as the beginning of a new democratic era. With varying emphases, such an account was shared by the Communists and those Social Democrats and the representatives of political centre who had formed the so-called peace opposition in the last phases of the Continuation War. This account gained widespread popularity, especially in the 1960s and 1970s.

The new post-war era could not be interpreted as an achievement of resistance, because no powerful resistance movement had existed in Finland. Nevertheless, one could with good reason argue that, after the national unity of the Winter War, significant left-wing political protests emerged and that a large machinery of ideological and repressive control of opinions was required for maintaining national cohesion in the time between the Winter War and the Continuation War, as well as during the Continuation War. Not only many Communists but also the leaders of the left-wing opposition of the Social Democratic Party languished in prison during the Continuation War. In the late 1940s, the concept of a 'Second Republic' was coined by the advocates of new policies. It did not refer to any constitutional change - the constitution of 1919 remained untouched - but was meant to point to the post-1944 changes in foreign policy (notably with regard to relations with the Soviet Union) and the widening of democracy, indicated by the legitimacy of Communism and the breakthrough of collective agreements in labour relations.

After the collapse of the Soviet Union, this interpretation, which pointed to the positive value of the post-war political changes drawing from the lessons of the lost war, was pushed aside. True, historians are currently conducting research on wartime control policies, the dark side of the collaboration with Nazi Germany, the harsh treatment of Soviet prisoners of war, and the practices of ethnic segregation in Russian Eastern Karelia (Aunesluoma 2013; Silvennoinen 2013). However, in public debates, those representing post-Cold War neopatriotic perspectives are influential, arguing in favour of the general 
legitimacy, correctness, and necessity of Finnish wartime decisions. Such a view also informs the way war veterans are widely respected both as a result of the sufferings and horrors they faced and for being the most significant actor group in the creation of contemporary Finland.

\section{War Veterans and Karelian Evacuees as Social Problems}

Many debaters in contemporary Finland regret that in the period before the collapse of the Soviet Union, and especially during the period of strong left-wing influence in the 1960s and 1970s, war veterans failed to achieve the respect they deserved. This claim tends to neglect the fact that the generation of war veterans was a powerful force in politics, the economy, and culture in the post-war decades, especially in the 1960s and 1970s, while at the same time facing the protests of a younger generation. An important aspect of the formation of the welfare state in post-war decades were policies aimed at defining and solving the social problems of war veterans and other groups hard hit by the war, especially the citizens of the ceded territories.

Social benefits, assistance, and care targeted at soldiers and their families were provided through manifold fragmented practices during the war years. These were coordinated at the end of the 1940s by legislation on pensions and compensation to disabled soldiers and the widows and children of fallen soldiers. The Finnish League of Companions in Arms had been banned after the Continuation War, but the Disabled War Veterans Association of Finland, founded after the Winter War in 1940, was an active initiator and organizer in these policy areas. Its effective fundraising campaigns included, for example, handling sales of Coca-Cola that was imported to Finland for the Helsinki Olympic Games in 1952.

Two in part rival national war veteran associations were founded in the late 1950s and early 1960s, and they played an important role in bringing war veteran pensions onto the political agenda. Legislation on war veteran pensions came into force in 1971, launching a system of means-tested pensions. In the following years, pension benefits were extended and increased, and since 1982 the war veteran pension system has also encompassed the women who had been involved - unarmedin warfare-associated tasks, many of them in the Lotta Svärd 
Organization banned after the Continuation War. A comprehensive system of healthcare and rehabilitation for aging war veterans was constructed and maintained by means of public funding, voluntary organizations, and popular fund-raising campaigns, strongly emphasizing the national 'debt of honour' of younger generations to war veterans (Sulamaa 2007; Uino 2014).

The Karelian population of the ceded territories was, after the 1944 armistice, permanently settled in Finland. Many evacuated families faced a massive post-war housing shortage in the cities (Palomäki 2011; Malinen 2014). However, the dominant policy was to give them homesteads in rural municipalities. The right to homesteads was extended also to war veterans and war widows and orphans. The huge project of settling Karelian people did not proceed without cultural friction and conflicts of economic interest. It involved large socioeconomic and cultural changes, but there was also strong continuity in the modes of thought and action concerning national agency and integration.

As late as 1940, about 60 per cent of the Finnish population earned their living from agriculture and forestry. The expansion of the rural class of small farmers, drawing from the experience of the Civil War of 1918, continued to be a major policy of national integration, and was also applied to the outcomes of World War II. The number of small-sized farms increased until the 1950s. The livelihood of farmers was dependent on the linkage between agriculture and wood processing industries through peasant-owned forests and, especially, the seasonal demand for labour in the logging industry.

As this linkage weakened through technological development and the subsequent diminished need for manpower in forestry, a change in socio-economic structures rapidly accelerated in the late 1950s and in the 1960s. The Finnish welfare state was built up by efforts to manage this very rapid and profound structural change and the simultaneous large-scale challenge of the very large baby boom cohorts entering schools and the workplace. Reforms to social policy and the educational system were an integral part of the establishment of an industrialized and urbanized wage-work society. While wartime and immediate post-war ideas on national integration had been premised on the continuity of rural Finland, wartime ways of defining urgent social problems and their solutions now provided elements for the ideational and institutional frameworks of these reforms. 
World War II enhanced an understanding of a modernizing nation-state society in which the objectives of economic rationalization, social integration, and individual self-discipline intersected. New and old elements were mixed in how such a society was conceived as a target of knowledge and reform. Concerns about the quantity and quality of population became effective arguments for rational societal planning.

After the Winter War, in 1941, the Population and Family Welfare Federation (Väestöliitto, now the Family Federation of Finland) was founded with a strong pronatalist spirit. After World War II, the federation, led by a leader of the Agrarian Party, became an active promoter of societal planning initiatives (Bergenheim 2017). Immediate solutions were needed for urgent problems. Among these were initiatives in housing policy, urged by the large number of returning soldiers and their families as well as evacuated Karelian families. After all, one had to recognize that rural colonization policies did not solve housing shortages in urban centres. The institution of state-subsided housing loans was legislated by a Social Democratic government in 1949 (Malinen 2014). Later, Väestöliitto sought to facilitate the education and employment of baby boom cohorts and made further efforts to control accelerating socio-economic and regional changes by means of science-based planning.

In wartime, concern about children's living conditions and malnutrition gave rise to a Nordic project, initiated by voluntary organizations and, in particular, by the Mannerheim League for Child Welfare (which was founded after the victory of the White General in the Civil War of 1918). The project transferred between 70,000 and 75,000 Finnish children to Sweden and, to a lesser extent, to Denmark, where they lived with families; the majority of them returned home after the war. The experiences of these 'war children' are one of the subjects of the current debate on the long-term mental consequences of war in Finland (Korppi-Tommola 2008, 445- 55). Concern about children's wellbeing and the nation's vitality also resulted, for example, in a parliamentary decision in 1943 that all primary schools must provide a free lunch to children (although the municipalities had five years within 
which to implement this decision). A bill on cash support to poor families with many children was passed in 1943.

Women's associations played a significant role in initiating and implementing wartime population and family policies. Many of their leading figures advocated urban, middle-class family ideals, but with limited success. In a rural society such as Finland, the gender division of labour never followed male-breadwinner ideals, and women-even married women-had also worked in manufacturing industries. The role of female labour power nevertheless increased significantly in all sectors of the economy during the course of the war. This change in the gender division of labour was only in part a temporary wartime phenomenon. The participation of women in industrial working life was supported by the fact that the shortage of labour power continued until the end of the 1940s, instead of the large-scale unemployment that had been expected to arise after the return of men from the front. True, the ideological impulses of wartime experiences were controversial. An ideal of family as a basic unit of society was actually reinforced by taxation, as later appears. A male-breadwinner model was advocated by both wartime and post-war proposals of family allowances as a part of a wage settlement. However, these proposals were soon rejected, and in 1948, at the same time as in other Nordic countries, child allowances began to be paid to all mothers. This was the first universal social benefit in Finland (Bergholm 2013, 315-19).

The quantity and quality of population as a target of knowledge and politics was interlinked with the issue of how best to fit individuals into the functions of society. This was an urgent problem on the wartime national agenda of politics and administration. Jobs became classified according to the amount of food and calories needed and people became categorized according to their occupational skills and political reliability. A classification of medical practices was needed in the treatment and employment of disabled soldiers, and the development of psychiatric methods was fostered by the need to somehow recognize the most acute and obvious forms of psychological damage. In the Continuation War, about 17,000 'shaken-up' soldiers were taken into psychiatric care and treated with new methods such as electrical and insulin shock treatment; yet, after the war, these individuals mostly failed to be recognized and classified as war invalids entitled to social support (Kivimäki 2013). 
Wartime experiences inspired institutional novelties in improving the quality of population and individual capacities. This was obvious in the foundation of the Institute of Occupational Health (Työterveyslaitos). The decision to set up this institute was made in 1945 and it was fully operational from 1951. The institute was initiated by young doctors and organized through the cooperation of governmental authorities, employer organizations, and trade unions. In the activities of the institute, the knowledge of physicians, engineers, and psychologists was combined. Models came not only from Sweden but also from the United States. The American pragmatist orientation inspired an attempt to combine different fields of scientific knowledge in seeking solutions to working-life problems. The Rockefeller Foundation gave significant economic support to the institute (Kettunen 1994, 378-92).

The promotion of economic efficiency, or a 'rationalization movement', had been discussed in Finland since the import of scientific management ideas prior to World War I. Although Finland was only indirectly involved in that war, linkages to the war economy of the Russian Empire provided some incentives for similar efforts to foster a more rational organization of urgent economic activities in a manner characteristic of the countries participating more fully in the conflict (Devinat 1927).

During World War II, rationalization was quite explicitly declared as a joint national task and necessity. To introduce and implement time and motion studies, the main method of Taylorism, a special office was founded in connection with the army headquarters. The German rationalization movement had inspired Finnish engineers since the early 1920s, and lessons were adopted from Germany during wartime as well. For many advocates of rationalization, the German mode was orientated to the common good of the people and the nation, and had thus a better 'spirit' than similar developments in America, where the interests of private companies were seen as being too dominant. Such a view was not always associated with sympathy towards the Nazi regime. Yet it was clear that the trade union leaders who were involved in wartime rationalization efforts did not look to German models of labour relations, but wished instead to associate British and Swedish ideas of industrial and economic democracy with rationalization (Kettunen 2001a, 235-55).

American management techniques were eagerly adopted in post-war employer policies of industrial companies. Finland did not join the 
Marshall Plan as the Soviet Union was opposed. However, Western, and especially American, connections played an important role. They were important not only in terms of international post-war social aid, but also for the ideological and practical flavour they gave to the way in which social problems were defined as targets of science-based knowledge. This was evident in the Institute of Occupational Health and also in the Institute of Industrial Supervisor Training (Teollisuuden Työnjohto-opisto, now the Management Institute of Finland) that was founded by employer organizations in 1945 for the defence of capitalist society. Courses of the American programme 'The Training Within Industry' were adopted in the late 1940s as part of the curriculum of the institute (Kettunen 1994, 355-61). More generally, American ideas of management became, in various ways, connected with the efforts of science-based societal planning, mixed with conclusions drawn from wartime experiences.

\section{The State as an Agent of Rational Planning}

In attempts to respond to immediate wartime needs, the ethos of economic and societal rationalization was reinforced in a way that combined different ideational ingredients from abroad with a notion of a national community as an agent defining and solving its own problems. This also implied a reinforced legitimacy of the state as an economic actor, regulator, redistributor, and provider.

Wartime rationalization efforts had been, on the one hand, focused on the acute tasks of exceptional circumstances, such as the management of hugely increased railway transportation, the reorganization of industrial production for military needs, and the erection of defensive fortifications, all of this by means of scarce and largely unskilled labour. These efforts were entwined with a greatly reinforced role of government in the national economy.

Annual state expenditure in the years 1940 to 1944 was about three times as high it had been in 1938. Military spending had increased in the 1930s and was in 1938 more than 20 per cent of state expenditure. In 1940, the proportion of military spending exceeded 80 per cent (Lehtinen 1967; Eloranta and Tanaka 2015). The increased spending was covered by several forms of revenue enhancement. In 1938, the government responded to the danger of war by raising income and 
property taxes by 20 per cent for military preparations, and additional increases as well as new forms of taxation were introduced during the wars (Jäntti 2006; Linnakangas 2015). A part of spending was covered by loans, about three quarters of which were domestic, and by printing notes (Lehtinen 1967).

On the other hand, the ethos of rationalization as a vital national task also linked together earlier international Great Depression conclusions concerning the need for national coordination of private economic action, or the 'rationalisation of rationalisation' as the ILO put it (International Labour Office 1931, 376), and wartime international ideas of 'post-war planning'. According to a widely shared view, increased state intervention implied a permanent shift in priorities and would only in part be removed after the war (Teräs 2013, 189-214).

In Finnish wartime debates, the New Deal, the Beveridge Plan, and Nazi social policies were all referred to as evidence of the new active role of the state in the future post-war world. After the war, the definition of national necessities and the content of state intervention clearly became a matter of political controversy. Yet even the Communists shared much of the mode of thought emphasizing economic rationalization as an urgent national task, not least due to their view that reparations to the Soviet Union-a crucial economic necessity for Finland until 1952 - were an anti-fascist and democratic national duty. Both the Communists and the Social Democrats interpreted their quite divergent socialist goals as a transition to true national economic rationality.

In reforms of taxation, responses to immediate wartime needs also implied long-term changes (Linnakangas 2015). Turnover tax was introduced in 1941. The collection of income tax was made more effective in 1943 by adopting a pay-as-you-earn system in which the employer withholds the tax. The administration of state and municipal taxation was reformed. The law on progressive income and property tax was revised in 1943.

One of the long-term changes proved to be a return to the joint taxation of spouses in 1943 legislation. In 1935, separate income taxation had been introduced, motivated by the marriage law of 1929 that prescribed the independence of wives in economic terms, but also by efforts to oppose the moral threat of unmarried cohabitation (Karppi 2008). In the return to joint taxation in 1943, fiscal calculations played a role, but it also reflected an ideal of the married couple as an economic unit, 
with the husband as the dominant partner. One interpretation of this is that the pattern of rural households had gained still more ideological power through the wartime subordination of individuals to joint effort, yet the return to joint taxation was paradoxical given the fact that the employment of married women in waged work had significantly increased in wartime. In 1976, separate taxation was again introduced, now in the Nordic wave of similar reforms and as an aspect of what Lars Trägårdh (1997) calls 'statist individualism' in the making of the Nordic welfare state.

National Necessities in the Post-War Making of the Welfare State

The immediate post-war period ended in the early 1950s, when reparations to the Soviet Union (mostly in the form of products of engineering industries that were largely extended) had been completed and the comprehensive system of rationing was dissolved. Now a more or less articulated national strategy of prosperity was widely adopted. It was based on a high rate of investment and the hope and assumption that sacrifices in the form of a more moderate growth of consumption would result in general prosperity in the future (Pohjola 1994, 237). A traditional mode of thought and action was reinforced in which social policies were assessed from the point of view of the limits imposed by economic resources.

A divergent argument, pointing to a virtuous circle between expanding social policies and economic growth, also emerged. It is evident in Pekka Kuusi's (1961) book on social policy for the 1960s, often characterized as the plan of the Finnish welfare state. Promoting social equality through the redistribution of income, social security and labour power policy would release people's productive capacities; the vicious circle between poverty and passivity would be broken. Nevertheless, in Kuusi's narrative, there was also a strong emphasis on national necessities. This derived from Finland's place in the world of international competition between national societies. Finland was situated between two highly dynamic and growth-oriented societies: Sweden and the Soviet Union. The mission Kuusi outlined was indeed a matter of life and death: if Finland was to survive between these two societies, 'we ourselves are doomed to grow' (Kuusi 1964, 59). 
Kuusi was not advocating any third way between the societal systems of Sweden and the Soviet Union. His argument was, rather, an example of the Finnish tendency to avoid any explicit association of social policy with Cold War confrontation. He located social policy in the sphere above - or beneath - the political and inter-systemic confrontations between East and West, in which the basic process was the evolution and growth of industrial society, with Sweden and the Soviet Union variously exemplifying the emergence of such a society. This implicit convergence ideology had obvious advantages for the national(istic) legitimization of social policies in the Cold War era.

Cold War inter-systemic confrontation was a significant factor behind socio-political considerations. Relatively strong support for Communism, in particular, was a major concern for all those who believed in social policies as a means of national social cohesion, and even for the political right, most notably the National Coalition Party, an actively anti-social policy stance was not a viable alternative (Smolander 2000). However, while the Swedish Social Democrats had integrated their policy objectives in 'democratic welfare politics' and contrasted it to capitalism and communism (Edling 2013), in Finland the dominant orientation was to depoliticize social policies. Thus, social reforms were often discussed as functional needs, pragmatic steps along the road of general progress within the limits of economic resources, or as issues of the pragmatic adjustment of conflicting interests in the name of the common national interest.

The left-wing majority governments of the period 1966-70 have remained in the history books as the ones that set the broad parameters of the welfare state in Finland into motion. Indeed, one may say that in the late 1960s the willingness to compromise reached a point where it became possible to gain broad political support for major Nordic-type reforms in social and educational policies as well as in industrial relations. However, the welfare state was no 'project' in Finland before it became, in the 1980s and 1990s, an achievement to be defended.

The concept of welfare state did not play any central role in how the socialist parties expressed their goals (Kettunen 2014). Moreover, important reforms of pension systems, sickness insurance, and unemployment policies had already been made in 1955-65, a period of great parliamentary instability (Bergholm 2009), and all of these social security reforms were achieved through political competition, interest conflicts, and compromises within the limits of what were conceived 
of as national economic and political necessities. These necessities were in the 1950s and 1960s associated with a profound socioeconomic and regional change that was preconditioned by the previous path-dependent way of dealing with the outcomes of war.

\section{Conclusion}

For an historical interpretation of the legacies of wars in the making of the Finnish welfare state, it is useful to pay attention to the combination of interest conflicts, on the one hand, and the emphasis on external necessities to be responded to by internal national will, on the other.

It is easy to find evidence for a conflict-laden past in Finland. The Civil War of 1918, with its class-based preconditions, had long-term effects through social memory and political institutions. In the post-World War II era, the relatively strong support of the Communists was one of the political phenomena that made Finland exceptional in the Nordic context. In industrial relations, obvious 'low-trust' elements remained until the 1980s, indicated by comparative strike statistics. The parliamentary system was unstable and short-lived governments were typical of Finland until the early 1980s.

However, an argument suggesting that, in Finland, there was a special emphasis on national consensus can easily be supported by referring to the historical record, as well. One may refer to the remarkable national unity during World War II, especially during the Winter War, with its long-term ideological legacy. During the Cold War, the political agenda and political agency were shaped by the necessity of coping with the tight limits for manoeuvre in international politics. Many economists and sociologists have also pointed out the special capability of the Finnish export industry to acquire hegemonic power through presenting its particular interests (international competitiveness) as the general national interest (e.g. Pekkarinen 1992; Kosonen 1993).

Arguably, the Finland of too much conflict and the Finland of too much consensus preconditioned each other (Kettunen 2004). The ideal of national consensus developed in the nineteenth-century nationbuilding that took place in the former Eastern provinces of the Swedish realm, after the Russo-Swedish war in 1808-9, within the framework of the Russian Empire. The strong consensus ideal tended to shape political conflicts into struggles about the right way and the privilege 
of speaking in the name of the whole, 'the people'. This kind of struggle can also be found as a significant aspect of the Civil War.

In the early 1960s, the sociologist Erik Allardt distinguished between four 'basic cleavages' of the Finnish society. They existed between the Finnish-speaking and Swedish-speaking Finns, between rural and urban Finns, between the working class and the bourgeoisie, and between the Communists and the rest of the people (Allardt 1964, 97131). One might argue that the political significance of these cleavages stemmed from their historical anchorage in rival claims of speaking in the name of 'the people' or the 'will of people'. Allardt observed that steps had been taken to recognize and regulate these cleavages and thus reinforce national integration. One should proceed in this direction, especially in relation to Communists. In the Durkheimian spirit, and inspired by the class conflict theory of Ralf Dahrendorf, Allardt concluded that, in a modern society with a deepening division of labour, social integration could only be reinforced by diminishing the pressure for conformity. Conflicts, when recognized and thus institutionalized, would promote integration and improve the performance capacity of the society.

This novel idea of national integration was seen as a way of overcoming the conflicts nourished by a strong demand for national consensus. However, as Risto Alapuro argues, it was actually compatible with another older feature of Finnish political culture, 'a curious combination of the demand for unanimity and the toleration of disagreement' $(1997,196)$. World War II experiences had reinforced this combination.

Wartime experiences fostered the notion of society as a functional whole that must and can be steered and rationalized by means of scientific knowledge. These experiences also created prerequisites for a problem definition focusing on how to fit different individuals into different functions of society. However, in addition to the level of large society and the level of different individuals, there was also a third level that was recognized as a target of problem-solving knowledge. It was found between society and the individual, a social sphere that could not be reduced to the norms and institutions of the societal system nor to the properties of individual people. This was discussed in sociological studies of the 1940s and 1950s concerning conflicts between official and unofficial norms and about the group dynamic as a force with its own autonomous laws, a phenomenon recognized in soldiers' 
collective behaviour in army units and later in post-war industrial working life (Kettunen 1997, 163-5).

One of the most influential treatments was that given by Väinö Linna in his novel The Unknown Soldier (1954). Linna's novel and sociological studies implied that disobedience and conflicts between official and unofficial norms were characteristic of Finnish culture and, moreover, that they could have a positive impact on the operations of an organization.

This line of argument re-emerged with new strength in 1960s sociological and sociologically inspired political discourse. By recognizing conflicts and institutionalizing them, it was suggested, the efficiency and cohesion of society could be improved. This argument achieved considerable influence in the politics of social policy, but it was still connected with the framing idea of the nation-state society as an historical agent that responds to external threats by means of its internal will and capacity.

Different historical layers can be found in the legacies of wars, and they seem to actualize in different phases of welfare-state history. Currently, the welfare state is modified to fulfil competition-state functions in a globalized economy, and that being so, the usefulness of conflicts is hardly a popular argument. The national 'we' appears as the creator of the welfare state in Finnish public discourse. Such a consensual belief seems to be more widely shared in Finland than in other Nordic countries, especially in Sweden, where a real struggle is going on between the Social Democrats and the bourgeois parties regarding ownership of the history of the welfare state (Kettunen et al. 2015, 867). Ideological associations to wartime joint efforts are evoked, for example, by the Finnish word talkoot, meaning that the members of the community voluntarily, out of an internal sense of duty, cooperate to fulfil an urgent task. This rural word was in constant use in the organization of home front activities during World War II, and remains popular in current political rhetoric. The need of national talkoot for rescuing the welfare state is a favourite phrase in advocating for austerity politics, consensual corporatism, improved competitiveness, and many other objectives. 


\section{References}

Ahlbäck, Anders. 2014. Manhood and the Making of the Military: Conscription, Military Service and Masculinity in Finland, 1917-39. Farnham: Ashgate.

Alapuro, Risto. 1988. State and Revolution in Finland. Berkeley, CA: University of California Press.

Alapuro, Risto. 1997. Suomen älymystö Venäjän varjossa. Helsinki: Tammi.

Allardt, Erik. 1964. 'Patterns of Class Conflict and Working Class Consciousness in Finnish Politics'. In Cleavages, Ideologies and Party Systems, edited by Erik Allardt and Yrjö Littunen, 97-131. Helsinki: Westermarck Society.

Anderson, Benedict. 1983. Imagined Communities: Reflections on the Origin and Spread of Nationalism. London \& New York: Verso.

Aunesluoma, Juhana. 2013. 'Two Shadows over Finland: Hitler, Stalin and the Finns Facing the Second World War as History 1944-2010'. In Hitler's Scandinavian Legacy John Gilmour and Jill Stephenson, 199-220. London: Bloomsbury Academic.

Bergenheim, Sophy. 2017. 'From Pronatalism to Salvaging Relationships: The Finnish Population and Family Welfare League's Conceptions of Marriage and Divorce, 1951-1988'. Scandinavian Journal of History 42: 1-20.

Bergholm, Tapio. 2009. 'The Making of the Finnish Model: The Qualitative Change in Finnish Corporatism in the Early 1960s'. Scandinavian Journal of History 34: 29-48.

Bergholm, Tapio. 2013. 'Decline of Civil Servant Privilege: A New Look at the Historical Development of Finnish Social Policy'. In Multilayered Historicity of the Present: Approaches to Social Science History, edited by Heidi Haggrén, Johanna Rainio-Niemi, and Jussi Vauhkonen, 313-25. Publications of the Department of Political and Economic Studies 8. Helsinki: University of Helsinki.

Devinat, Paul. 1927. Scientific Management in Europe. Studies and Reports, Series B (Economic Conditions). Geneva: International Labour Office. 
Edling, Nils. 2013. 'The Primacy of Welfare Politics. Notes on the Language of the Swedish Social Democrats and their Adversaries in the 1930s'. In Multilayered Historicity of the Present: Approaches to Social Science History, edited by Heidi

Haggrén, Johanna Rainio-Niemi, and Jussi Vauhkonen, 125-50. Publications of the Department of Political and Economic Studies 8. Helsinki: University of Helsinki.

Eloranta, Jari and Yasushi Tanaka. 2015. 'Military Spending in Japan and Finland: From Warfare to Welfare'. In Comparing Post-War Japanese and Finnish Economies and Societies:

Longitudinal Perspectives, edited by Yasushi Tanaka, Toshiaki Tamaki, Jari Ojala, and Jari Eloranta, 71-91. London \& New York: Routledge.

Haapala, Pertti. 2014. 'The Expected and Non-Expected Roots of Chaos: Preconditions of the Finnish Civil War'. In The Finnish Civil War in 1918: History, Memory, Legacy, edited by Tuomas Tepora and Aapo Roselius, 21-50. Leiden \& Boston, MA: Brill.

Häkkinen, Antti and Henrik Forsberg. 2015. 'Finland's "Famine Years" of the 1860s: A Nineteenth-Century Perspective'. In Famines in European Economic History: The Last Great European Famines Reconsidered, edited by Declan Curran, Ludomyr Luciuk, and Andrew G. Newby, 99-123. New York: Routledge.

International Labour Office. 1931. The Social Aspects of Rationalisation: Introductory Studies. Studies and Reports, Series B (Economic Conditions) No. 18. Geneva: International Labour Office.

Jäntti, Markus. 2006. 'Income Distribution in the 20th Century'. In The Road to Prosperity: An Economic History of Finland, edited by In Jari Ojala, Jari Eloranta, and Jukka Jalava, 245-60. Helsinki: Suomalaisen Kirjallisuuden Seura.

Julkunen, Raija and Jussi Vauhkonen. 2006. 'Suomalainen ihme'. In Historiallinen käänne. Johdatus pitkän aikavälin historian tutkimukseen, edited by Juho Saari, 289-319. Helsinki: Gaudeamus. Jussila, Osmo. 1999. 'Finland as a Grand Duchy 1809-1917'. In From Grand Duchy to a Modern State: A Political History of Finland since 1809, edited by Osmo Jussila, Seppo Hentilä, and Jukka Nevakivi, 198. London: Hurst \& Company. 
Kaarninen, Mervi. 2008. Punaorvot 1918. Helsinki \& Jyväskylä: Minerva Kustannus.

Karppi, Hanna-Leena. 2008. Aviopuolisoiden verotus ja kaksijakoinen kansalaisuus. Vuosien 1935 ja 1943 verotusuudistukset sosiaalisen sukupuolijärjestelmän ilmentäjinä. MA diss., Political History, University of Helsinki.

Kettunen, Pauli. 1976. Anoen, taistellen, neuvotellen. Veturimiesten ammattiyhdistystoiminnan kehitys vuoteen 1976. Helsinki: Suomen Veturimiesten Liitto.

Kettunen, Pauli. 1994. Suojelu, suoritus, subjekti. Työsuojelu teollistuvan Suomen yhteiskunnallisissa ajattelu- ja toimintatavoissa. With an English Summary: Protection, Performance, and Subject: Labour Protection and the Social Modes of Thought and Action in Finland, c.1880-1950. Historiallisia Tutkimuksia 189. Helsinki: Suomen Historiallinen Seura.

Kettunen, Pauli. 1997. Työjärjestys. Tutkielmia työn ja tiedon poliittisesta historiasta. Helsinki: Tutkijaliitto.

Kettunen, Pauli. 2001a. 'Modelle aus Deutschland zur Rationalisierung der Arbeit in Finnland'. In Pro Finlandia 2001. Festschrift für Manfred Menger, edited by Fritz Petrick and Dörte Putensen, 235-55. Reinbek: Traute Warnke Verlag.

Kettunen, Pauli. 2001b. 'The Nordic Welfare State in Finland'. Scandinavian Journal of History 26: 226-47.

Kettunen, Pauli. 2004. 'The Nordic Model and Consensual Competitiveness in Finland'. In Between Sociology and History: Essays on Microhistory, Collective Action, and Nation-Building, edited by Anna-Maija Castrén, Markku Lonkila, and Matti Peltonen, 289309. Helsinki: SKS/Finnish Literature Society.

Kettunen, Pauli. 2006. 'The Power of International Comparison: A Perspective on the Making and Challenging of the Nordic Welfare State'. In The Nordic Model of Welfare: A Historical Reappraisal, edited by Niels Finn Christiansen, Klaus Petersen, Nils Edling, and Per Haave, 31-65. Copenhagen: Museum Tusculanum Press.

Kettunen, Pauli. 2013. 'The ILO as a Forum for Developing and Demonstrating a Nordic Model'. In Globalizing Social Rights:The International Labour Organisation and Beyond, edited by Sandrine 
Kott and Joelle Droux, 210-30. Basingstoke \& New York: Palgrave Macmillan.

Kettunen, Pauli. 2014. 'The Language of Social Politics in Finland'. In Daniel Béland and Klaus Petersen (eds), Analysing Social Policy Language: Comparative and Transnational Perspectives, 157-75. Bristol: Policy Press.

Kettunen, Pauli, Urban Lundberg, Mirja Österberg, and Klaus Petersen. 2015. 'The Nordic Model and the Rise and Fall of Nordic Cooperation'. In Nordic Cooperation: A European Region in Transition, edited by Johan Strang, 69-91. London \& New York: Routledge.

Kinnunen, Tiina and Ville Kivimäki, eds. 2012. Finland in World War II: History, Memory, Interpretations. Leiden: Brill.

Kivimäki, Ville. 2013. Battled Nerves: Finnish Soldiers' War Experience, Trauma, and Military Psychiatry, 1941-44. Turku: Åbo Academi University.

Klinge, Matti. 1993. The Finnish Tradition: Essays on Structures and Identities in the North of Europe. Helsinki: Finnish Historical Society.

Korppi-Tommola, Aura. 2008. 'War and Children in Finland during the Second World War'. Paedagogica Historica 44: 445-55.

Koselleck, Reinhart. 1979. Vergangene Zukunft. Zur Semantik geschichtlichen Zeiten. Frankfurt a.M.: Suhrkamp.

Kosonen, Pekka. 1993. 'The Finnish Model and the Welfare State in Crisis'. In The Nordic Welfare State as a Myth and as Reality, edited by Pekka Kosonen, 45-66. Renvall Institute Publications 5. Helsinki: Renvall Institute, University of Helsinki.

Kurunmäki, Jussi. 2011. "Nordic Democracy” in 1935: On the Finnish and Swedish Rhetoric of Democracy'. In Rhetorics of Nordic Democracy, edited by Jussi Kurunmäki and Johan Strang, 37-82. Helsinki: Finnish Literature Society.

Kuusi, Pekka. 1961. 60-luvun sosiaalipolitiikka. Porvoo: WSOY.

Kuusi, Pekka. 1964. Social Policy for the Sixties: a Plan for Finland. Helsinki: Finnish Social Political Association.

Lehtinen, Artturi. 1967. 'Sotatalous 1939-1945'. In Itsenäisen Suomen taloushistoriaa 1919-1950, edited by Eino Jutikkala, Matti J. Castren, 
Hugo E. Pipping, and Markku Järvinen, 193-233. Historian Aitta 17. Porvoo and Helsinki: WSOY.

Lindberg, Valter. 1934. Utvecklingen av den allmänna inkomstskatten $i$ Finlands statsskattesystem. Akademisk avhandling. Helsingfors: Helsingfors Universitet.

Linna, Väinö. 1954. Tuntematon sotilas. Porvoo: WSOY [1957. The Unknown Soldier. London: Collins].

Linnakangas, Esko. 2015. 'Tuloverotuksen synty ja kehtys'. Verotus Suomessa 1865-2015, 7-18. Helsinki: Verohallinto.

Malinen, Antti. 2014. Perheet ahtaalla. Asuntopula ja siihen sopeutuminen toisen maailmansodan jälkeisessä Helsingissä 19441948. Helsinki: Väestöliitto.

Palomäki, Antti. 2011. Juoksuhaudoista jälleenrakennukseenSiirtoväen ja rintamamiesten asutus- ja asuntokysymyksen järjestäminen ja sen käänteentekevä vaikutus asuntopolitiikkaan ja kaupunkirakentamiseen. Tampere: Tampere University Press.

Pekkarinen, Jukka. 1992. 'Corporatism and Economic Performance in Sweden, Norway, and Finland'. In Social Corporatism: A Superior Economic System?, edited by Jukka Pekkarinen, Matti Pohjola, and Bo Rowthorn, 297-337. Oxford: Oxford University Press.

Petersen, Klaus. 2006. 'Constructing Nordic Welfare? Nordic Social Political Cooperation 1919-1955'. In The Nordic Model of Welfare: A Historical Reappraisal, edited by Niels Finn Christiansen, Klaus Petersen, Nils Edling, and Per Haave, 67-98. Copenhagen: Museum Tusculanum Press.

Pohjola, Matti. 1994. 'Nordic Corporatism and Economic Performance: Labour Market Equality at the Expense of Productive Efficiency?' In Transformation of the Nordic Industrial Relations in the European Context, edited by Timo Kauppinen and Virpi Köykkå, 223-41. IIRA 4th European Regional Congress, Helsinki, Finland 246 August, 1994. Helsinki: The Finnish Labour Relations Association. Polvinen, Tuomo. 1962. Die Finnischen Eisenbahnen in den militärischen und politischen Plänen Russlands vor dem ersten Weltkrieg. Helsinki: Societas Historica Finlandiae.

Pulkkinen, Tuija. 1999. 'One Language, One Mind. The Nationalist Tradition in Finnish Political Culture'. In Europe's Northern Frontier: 
Perspectives on Finland's Western Identity, edited by Tuomas M. S.

Lehtonen. Jyväskylä: PS-Kustannus.

Rainio-Niemi, Johanna. 2008. Small State Cultures of Consensus:

State Traditions and Consensus-Seeking in the Neo-Corporatist and Neutrality Policies in Post-1945 Austria and Finland. PhD diss., University of Helsinki.

Saarela, Tauno. 2014. 'To Commemorate or Not: The Finnish

Labor Movement and the Memory of the Civil War in the

Interwar Period'. In The Finnish Civil War in 1918: History, Memory, Legacy, edited by Tuomas Tepora and Aapo Roselius, 331-62. Leiden and Boston, MA: Brill.

Screen, J. E. O. 1996. The Finnish Army 1881-1901: Training the Rifle Battalions. Studia Historica 54. Helsinki: Finnish Historical Society.

Siltala, Juha. 2014. 'Being Absorbed into an Unintended War'. In The Finnish Civil War in 1918: History, Memory, Legacy, edited by Tuomas Tepora and Aapo Roselius, 51-89. Leiden \& Boston, MA: Brill.

Silvennoinen, Oula. 2013. 'Janus of the North? Finland 1940-44: Finland's Road into Alliance with Hitler'. In Hitler's Scandinavian Legacy, edited by John Gilmour and Jill Stephenson, 129-46. London: Bloomsbury Academic.

Smolander, Jyrki. 2000. Suomalainen oikeisto ja 'kansankoti'. Kansallisen Kokoomuksen suhtautuminen pohjoismaiseen hyvinvointivaltiomalliin jälleenrakennuskaudelta konsensusajan alkuun. Bibliotheca Historica 63. Helsinki: Suomalaisen Kirjallisuuden Seura.

Spector, Malcolm and John I. Kitsuse. 2011. Constructing Social Problems. New Brunswick, NJ and London: Transaction Publishers.

Sulamaa, Kaarle. 2007. Veteraania ei jätetä. Suomen Sotaveteraaniliitto 1957-2007. Helsinki: Edita.

Teräs, Kari. 2013. 'Private Entrepreneurship and the State: Discursive Power Struggles during the Regulated Economy 1939-1949'. In Multilayered Historicity of the Present: Approaches to Social Science History, edited by Heidi Haggrén, Johanna Rainio-Niemi, and Jussi Vauhkonen, 189-214. Publications of the Department of Political and Economic Studies 8. Helsinki: University of Helsinki. 
Trägårdh, Lars. 1997. 'Statist Individualism: On the Culturality of the Nordic Welfare State'. In The Cultural Construction of Norden, edited by Øystein Sørensen and Bo Stråth, 253-85. Oslo: Scandinavian University Press.

Uino, Ari. 2014. Sotiemme veteraanit. Rintamalta rakentamaan. Kirjokansi 65. Helsinki: Suomalaisen Kirjallisuuden Seura.

Upton, Anthony F. 1980. The Finnish Revolution 1917-1918. Minneapolis, MN: University of Minnesota Press.

Urponen, Kyösti. 1994. 'Huoltoyhteiskunnasta hyvinvointivaltioon'. In Armeliaisuus, yhteisöapu, sosiaaliturva. Suomalaisten sosiaalisen turvan historia, edited by Jouko Jaakkola, Panu Pulma, Mirja Satka, and Kyösti Urponen, 163-260. Helsinki: Sosiaaliturvan Keskusliitto. Waris, Heikki. 1973. Suomalaisen yhteiskunnan sosiaalipolitiikka, 5th edition. Porvoo: WSOY. 